\title{
PENGEMBANGAN GROUP INVESTIGATION DENGAN PERMAINAN “AKU SEORANG DETEKTIF” KELAS IV SD MUHAMMADIYAH 1 MALANG
}

\author{
Renika Arisinta $^{1)}$, Bayu Hendro Wicaksono ${ }^{2)}$, Ima Wahyu Putri Utami ${ }^{3)}$ \\ Universitas Muhammadiyah Malang \\ e-mail: Arisinta.sinta@gmail.com
}

\begin{abstract}
The type of research conducted is Research and Development (RnD). In this research aiming to produce product development of Group Investigation(GI) learning model with game "Aku Seorang detektif" in class IV SD Muhammadiyah 1 Malang that worthy with criteria valid, effective, and interesting. In developing the Group Investigation(GI) model, the design of the ADDIE Model consists of five steps: (1) analysis, (2) design, (3) development, (4) application, (5) evaluation. The results showed (1) Development of GI learning model with game "Aku Seorang detektif" in class IV SD Muhammadiyah 1 Malang stated very valid. This is indicated by manual guidance value of $89 \%$, RPP validation of $98 \%$, and game and media validation of $92 \%$. (2) The development of the GI learning model with the game "aku seorang detektif" is stated very effective. This is indicated by the value of teacher response during the PBM of $86 \%$. (3) The development of the GI learning model with the game "Aku seorang detektif" is very interesting. This is indicated by student responses of $95 \%$ of interested students and $5 \%$ of students who are less interested.
\end{abstract}

Keywords: development, teachings model GI, "Aku Seorang Detektif” games

Abstrak: Jenis penelitian yang dilakukan adalah Reaserch and Development(RnD). Penelitian ini bertujuan untuk menghasilkan produk pengembangan model pembelajaran Group Investigation(GI) dengan permainan "Aku Seorang Detektif” kelas IV SD Muhammadiyah 1 yang layak dengan kriteria valid, efektif, dan menarik. Dalam mengembangkan model Group Investigation(GI), digunakan rancangan ADDIE Model yang terdiri atas lima langkah, yaitu : (1) analisis, (2) perancangan, (3) pengembangan, (4) penerapan, (5) evaluasi. Hasil penelitian menunjukkan (1) Pengembangan model pembelajaran GI dengan permainan "aku seorang detektif" kelas IV SD Muhammadiyah 1, Malang dinyatakan sangat valid. Hal ini ditunjukkan dengan nilai validasi buku pedoman sebesar $89 \%$, validasi RPP sebesar $98 \%$, serta validasi permainan dan media sebesar 92\%. (2) Pengembangan model pembelajaran GI dengan permainan "aku seorang detektif" dinyatakan sangat efektif. Hal ini ditunjukkan dengan nilai respon guru selama PBM sebesar 86\%. (3) Pengembangan model pembelajaran GI dengan permainan "aku seorang detektif" dinyatakan sangat menarik. Hal ini ditunjukkan dengan respon siswa sebesar 95\% siswa yang tertarik dan $5 \%$ siswa yang kurang tertarik.

Kata Kunci: Model Pembelajaran GI, Permainan "Aku Seorang Detektif”, gaya dan gerak

\section{PENDAHULUAN}

Pembelajaran tematik merupakan suatu pembelajaran yang melibatkan beberapa mata pelajaran untuk memberikan pengalaman yang bermakna bagi siswa. Keterpaduan pembelajaran, dapat dilihat dari aspek proses atau waktu, aspek kurikulum, dan aspek belajar mengajar (Majid, 2014: 86). Dari pernyataan tersebut, pembelajaran tematik adalah pembelajaran terpadu yang menggunakan tema sebagai pemersatu materi dalam beberapa mata pelajaran sekaligus dalam satu kali pertemuan.

Sesuai arahan Permendikbud No. 22 tahun 2016 tentang standart proses sekolah dasar dan menengah ( dalam BSNP, 2009:1), proses pembelajaran pada satuan pendidikan hendaknya diselenggarakan secara interaktif, inspiratif, menyenangkan, menantang, memotivasi peserta didik untuk berpartisipasi aktif, serta memberikan ruang yang cukup bagi prakarsa, kreativitas, dan kemandirian sesuai dengan bakat, minat, dan perkembangan fisik serta psikologis peserta didik. Melalui proses pembelajaran interaktif, inspiratif, dan menyenangkan, peserta didik diharapkan dapat memperoleh proses pembelajaran yang bermakna dalam rangka mengembangkan potensinya. IPA merupakan cara mencari tahu tentang alam secara sistematis untuk menguasai pengetahuan, fakta-fakta, konsep-konsep, prinsip-prinsip, proses penemuan, dan memiliki sikap ilmiah. IPA merupakan hasil kegiatan manusia berupa pengetahuan, gagasan, dan konsep yang terorganisasi tentang alam sekitar yang diperoleh dari pengalaman melalui serangkaian proses ilmiah antara lain penyelidikan, penyusunan dan penyajian gagasan (Supriyanti, 2010:12). Dari pernyataan tersebut dapat disimpulkan bahwa pembelajaran IPA merupakan 
mencari tahu tentang alam sekitar yang diperoleh dari pengalaman melalui serangkaian tahapan pada proses ilmiah.

Berdasarkan hasil wawancara dan hasil observasi pada 10 Desember 2016 dengan guru kelas IV-B di SD Muhammadiyah 1 Malang saat proses belajar mengajar pembelajaran tematik khususnya pada mata pelajaran IPA materi gaya dan gerak, ditemukan bahwa (1) guru kurang berinteraksi dan metode pembelajaran yang digunakan masih metode ceramah namun pernah menggunakan Model Group Investigation(GI), (2) siswa kurang aktif dalam hal berkomunikasi terkait pembelajaran, dan (3) pembelajaran gaya dan gerak terpacu pada Buku Siswa dan Buku Guru. Dengan demikian, guru kurang maksimal dalam mengemas model pembelajaran group investigation yang menarik dan menyenangkan bagi siswa.

Pemilihan model GI dirasa cocok jika dipasangkan dengan permainan tersebut karena model pembelajaran kooperatif tipe group investigation dapat memberikan kesempatan bagi siswa untuk berpartisipasi dalam memecahkan masalah dengan benda konkret yang dikaji antar individu dalam suatu kelompok. Selain itu model GI lebih menekankan pada proses pencarian pengetahuan dari pada transfer pengetahuan. Maka dilakukanlah penelitian yang berjudul "Pengembangan Model Pembelajaran Group Investigation (GI) dengan Permanainan "Aku Seorang Detektif" dalam Materi Gaya dan Gerak Kelas IV SD Muhammadiyah 01 Malang".

\section{METODE}

Penelitian dan pengembangan atau Research and Development (RnD) atau sering disebut pengembangan adalah strategi atau metode penelitian yang cukup ampuh untuk memperbaiki praktik pembelajaran. Penelitian dan pengembangan adalah rangkaian proses atau langkah-langkah dalam rangka mengembangkan suatu produk baru atau memperbaiki produk-produk yang telah ada agar dapat dipertanggungjawabkan (Tegeh, 2014:8).

Dalam penelitian dan pengembangan ini, menggunakan rancangan dari ADDIE Model. Model ADDIE terdiri atas lima langkah, yaitu : (1) analisis, (2) perancangan, (3) pengembangan, (4) penerapan, (5) evaluasi. Tahap analisis meliputi kegiatan melakukan analisis kompetensi yang dituntut kepada peserta didik,melakukan analisis karakteristik, dan melakukan analisis materi sesuai dengan tuntutan kompetensi. Tahap perancangan dilakukan dengan kerangka acuan peserta didik, kompetensi, strategi belajar, asesmen dan evaluasi. Tahap pengembangan adalah kegiatan pengembangan yang pada intinya adalah kegiatan menerjemahkan spesifikasi desain ke dalam bentuk fisik, sehingga kegiatan ini menghasilkan prototype produk pengembangan. Tahap Implementasi adalah hasil pengembangan yang diterapkan dalam pembelajaran untuk mengetahui pengaruhnya terhadap kualitas pembelajaran yang meliputi keefektifan,kemenarikan dan efisiensi pembelajaran. Tahap evaluasi adalah tahap evaluasi terhadap kesatuan atau keseluruhan produk pengembangan (Tegeh, 2014:42).

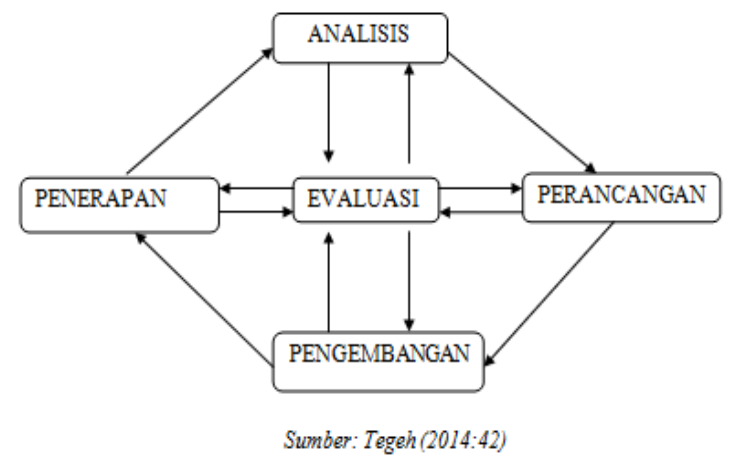

Gambar 2.1: Tahapan Model Pengembangan ADDIE

Teknik analisis data pada penelitian dan pengembangan ini dengan cara 
teknik analisis kuantitif dan kualitatif. Teknik analisis data ini, disesuaikan dengan rumusan masalah sebagai berikut "bagaimanakah proses pembuatan pengembangan model pembelajaran group investigation (GI) dengan permanainan "aku seorang detektif" dalam materi gaya dan gerak pada kelas IV SD Muhammadiyah 1 malang yang layak dengan kriteria valid, efektif, dan menarik?". Adapun teknik analisis lebih detail dipaparkan sebagai berikut:

1. Data kuantitatif

a. Kevalidan

Data kevalidan diambil dari hasil validator ahli permainan yaitu Bapak Kuncahyono, M.Pd selaku ahli permainan dan Bapak Ahmad Hafidh Imaduddin, S.Pd sebagai ahli materi. Data kuantitatif yaitu berdasarkan hasil angket berupa persentase dari Hasil Instrumen RPP, Hasil Instrumen Buku Panduan, dan Hasil Instrumen Permainan dan Media Pendukung Permainan.

Tabel 3.8 Kisi-Kisi Pedoman Kevalidan Analisis Data Dalam Persentase

\begin{tabular}{|c|c|c|}
\hline No. & $\begin{array}{l}\text { Tingkat } \\
\text { Pencapaian }\end{array}$ & Keterangan \\
\hline 1. & $\begin{array}{l}85,01 \%- \\
100 \%\end{array}$ & $\begin{array}{l}\text { Sangat valid atau dapat } \\
\text { digunakan tanpa } \\
\text { perbaikan. }\end{array}$ \\
\hline 2. & $\begin{array}{l}70,01 \%- \\
85,00 \%\end{array}$ & $\begin{array}{l}\text { Cukup valid atau dapat } \\
\text { digunakan namun perlu } \\
\text { perbaikan kecil. }\end{array}$ \\
\hline 3. & $\begin{array}{l}50,01 \%- \\
70,00 \%\end{array}$ & $\begin{array}{l}\text { Kurang valid atau } \\
\text { disarankan tidak } \\
\text { dipergunakan karena perlu } \\
\text { revisi besar. }\end{array}$ \\
\hline 4. & $\begin{array}{l}01,00 \%- \\
50,00 \%\end{array}$ & $\begin{array}{l}\text { Tidak valid atau tidak bisa } \\
\text { digunakan. }\end{array}$ \\
\hline
\end{tabular}

\section{b. Keefektifan}

Data keefektifan diambil dari hasil respon guru yaitu Bapak Ahmad Hafidh Imaduddin, S.Pd sebagai ahli materi selaku pengguna produk. Data kuantitatif yaitu berdasarkan hasil angket berupa persentase dari Hasil Angket Respon Guru selaku Pelaksana Pembelajaran.

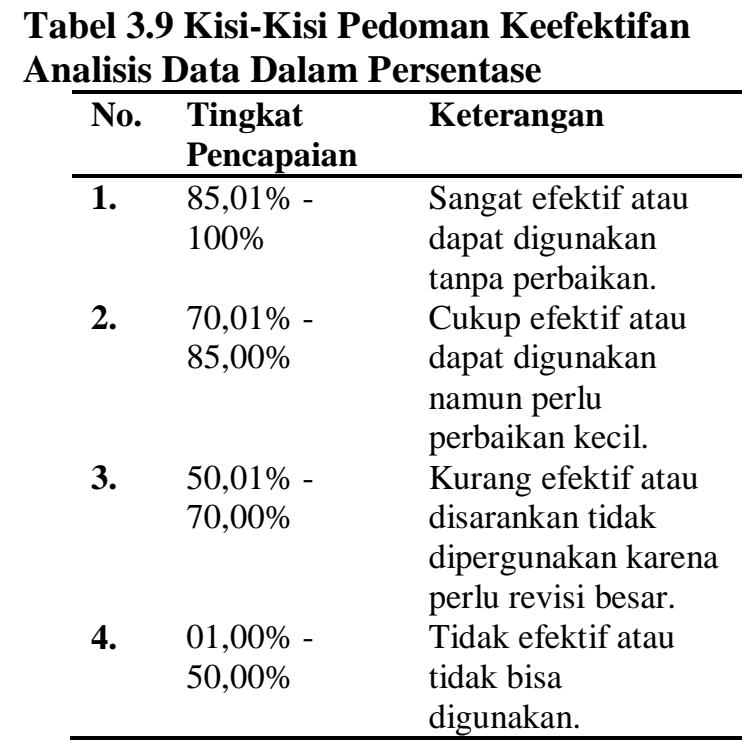

(Sumber: Akbar, 2016:157)

c. Kemenarikan

Data kemenarikan diambil dari hasil respon siswa sebanyak 22 siswa. Data kuantitatif yaitu berdasarkan hasil angket berupa persentase dari Hasil Angket Respon Siswa.

Tabel 3.10 Kisi-Kisi Pedoman

Kemenarikan Analisis Data Dalam

Persentase

\begin{tabular}{|c|c|c|}
\hline No. & $\begin{array}{l}\text { Tingkat } \\
\text { Pencapaian }\end{array}$ & Keterangan \\
\hline 1. & $\begin{array}{l}85,01 \%- \\
100 \%\end{array}$ & $\begin{array}{l}\text { Sangat efektif atau } \\
\text { dapat digunakan } \\
\text { tanpa perbaikan. }\end{array}$ \\
\hline 2. & $\begin{array}{l}70,01 \%- \\
85,00 \%\end{array}$ & $\begin{array}{l}\text { Cukup efektif atau } \\
\text { dapat digunakan } \\
\text { namun perlu } \\
\text { perbaikan kecil. }\end{array}$ \\
\hline 3. & $\begin{array}{l}50,01 \%- \\
70,00 \%\end{array}$ & $\begin{array}{l}\text { Kurang efektif atau } \\
\text { disarankan tidak } \\
\text { dipergunakan karena } \\
\text { perlu revisi besar. }\end{array}$ \\
\hline 4. & $\begin{array}{l}01,00 \%- \\
50,00 \%\end{array}$ & $\begin{array}{l}\text { Tidak efektif atau } \\
\text { tidak bisa } \\
\text { digunakan. }\end{array}$ \\
\hline
\end{tabular}

(Sumber: Akbar, 2016:158)

2. Data kualitatif

Data kualitatif diambil dari saran dan kritik yang dianalisis sebagai acuan revisi RPP dan Buku Panduan. Saran dan kritik RPP didapat dari saran dari respon guru ketika menggunakan RPP, respon siswa dan validasi RPP. Sedangkan 
saran dan kritik Buku Panduan didapat dari respon guru ketika menggunakan RPP, validasi Buku Panduan, dan validasi permainan dan media pendukung permainan. Perolehan data dari hasil penilaian kevalidan, keefektifan dan kemenarikan dianalisis dengan rumus dibawah ini (Akbar, 2016:82) :

Presentase skor $=\frac{\text { jumlah skor penilaian }}{\text { Skor penilaian maksimal }} \times 100 \%$

Dari kedua data tersebut dapat disimpulkan bahwa data kualitatif dan data kuantitatif sebagai dasar revisi produk. Data tersebut nantinya akan disimpulkan, dimana data kuantitatif sebagai hasil dalam bentuk persentase dan kualitatif sebagai hasil dalam bentuk deskripsi.

\section{HASIL DAN PEMBAHASAN}

Perangkat pembelajaran yang dikembangkan dalam penelitian ini meliputi Rencana Pelaksanaan Pembelajaran (RPP) dan Buku Panduan. Model pengembangan pada penelitian ini mengacu pada model ADDIE yang terdiri dari lima tahapan (Tegeh, 2014:42) yaitu analisis (Analysis), perancangan (Design), pengembangan (Development), penerapan (Implementation), dan evaluasi (Evaluation). Penelitian yang berjudul Pengembangan Model Pembelajaran GI dengan Permainan "Aku Seorang Detektif" dalam materi gaya dan gerak ini dilaksanakan di SD Muhammadiyah 1 Malang. Peneliti melakukan penelitian ini sejak bulan Desember sampai dengan Maret 2017.

Berdasarkan data penelitian yang telah dilakukan oleh peneliti maka diperoleh hasil saat proses belajar mengajar pembelajaran tematik khususnya pada mata pelajaran IPA materi gaya dan gerak, ditemukan bahwa (1) guru kurang berinteraksi dengan siswa dan metode pembelajaran yang digunakan masih metode ceramah namun sesekali pernah menggunakan model group investigation, (2) Siswa kurang aktif dalam hal berkomunikasi terkait pembelajaran, dan (3) Pembelajaran gaya dan gerak siswa terpacu pada Buku Siswa dan Buku Guru. Dengan demikian, guru kurang maksimal dalam mengemas model pembelajaran group investigation yang menarik dan menyenangkan bagi siswa. Hasil diperoleh dari proses pembuatan produk yang sesuai dengan model ADDIE.

\section{Analisis}

Analisis kompetensi yang dituntut siswa yaitu 1) pernah melakukan model group investigation; 2) memahami perbedaan tarikan dan dorongan; dan 3)siswa memahami pengertian, manfaat dan macam-macam gaya. Dengan melakukan analisis kompetensi, penelitian dapat melanjutkan pada analisis karakteristik.

Analisis karakteristik dari penelitian ini yaitu diketemukan pada saat melakukan observasi dan wawancara pada kelas IV B. Dari kedua kegiatan tersebut ditemukan bahwa proses belajar mengajar masih di dominasi kegiatan yang berpusat pada guru melalui metode ceramah. Guru pernah menggunakan model pembelajaran GI namun masih lebih banyak menggunakan metode ceramah. Hal tersebut menyebabkan (a) guru kurang berinteraksi dengan siswa dan metode pembelajaran yang digunakan masih metode ceramah namun sesekali pernah menggunakan model group investigation,; (b) siswa kurang aktif dalam berkomunikasi terkait pembelajaran; dan (c) pembelajaran gaya dan gerak siswa berpacu pada buku siswa dan buku guru. Hal ini dibuktikan pada tabel 4.1 hasil observasi dan pada tabel 4.2 hasil wawancara.

Analisis materi ditemukan bahwa mata pelajaran yang masih sulit dikuasai siswa yaitu IPA pada materi gaya dan gerak pada kelas IV B dengan jumlah siswa sebanyak 22 siswa. Solusi dalam mengatasi hal tersebut maka salah 
satunya adalah perlu dikembangkannya model Group Investigation dengan permainan "Aku Seorang Detektif" pada pembelajaran tematik tema 8 , subtema 1 , dan pembelajaran 1 .

Berdasarkan hasil observasi di SD Muhammadiyah 1 Malang, dapat disimpulkan bahwa siswa masih kurang dalam menunjukkan respon pada saat proses belajar mengajar berlangsung atau siswa masih pasif dalam proses belajar mengajar. Pada aspek melakukan sesuatu dan mengkomunikasikan terkait pembelajaran atau psikomotor siswa juga masih kurang. Pada aspek berfikir reflektif, siswa juga masih kurang dalam menyimpulkan materi pembelajaran.

Hasil Wawancara dapat disimpulkan bahwa guru masih banyak menggunakan metode ceramah dan pernah melakukan model pembelajaran GI. Dengan menggunakan metode ceramah, anak cenderung bosan dan kurang aktif.

Berdasarkan hasil observasi dan wawancara yang dilakukan, dapat disimpulkan bahwa terciptanya sebuah model pembelajaran dengan permainan yang layak dengan kriteria valid, efektif, dan menarik sehinggga siswa dapat berperan aktif, menumbuhkan sikap kerjasama tim serta dapat berkomunikasi terkait pembelajaran pada siswa kelas IV B SD Muhammadiyah 1 Malang.

\section{Perancangan}

Pada tahap desain ini, peneliti menentukan kompetensi khusus yang dicapai oleh siswa, metode, bahan ajar, strategi pembelajaran serta media pembelajaran. Dalam produk ini menghasilkan RPP dan Buku panduan. RPP ini sebagai rencana pelaksanaan pembelajaran model GI dengan permainan "Aku Seorang Detektif". RPP akan dilaksanakan pada kelas IV SD, tema 8 , subtema 1 , pembelajaran ke-1, serta mata pelajaran IPA dan Bahasa Indonesia. RPP ini berisi tentang KI, KD, Indikator, tujuan pembelajaran, pendekatan dan metode, langkah-langkah pembelajaran, sumber dan media, evaluasi, LKS, soal dan kunci jawaban. Pendekatan dan metode yang digunakan yaitu pendekatan scientific, model pembelajaran Group Investigation (GI) dengan permainan "Aku Seorang Detektif" serta strategi pembelajaran tidak langsung dan pembelajaran interaktif. Media yang digunakan yaitu kartu berkata, kaca pembesar, kantong misi, lembar kerja siswa, dan soal post test. Evaluasi berisi tentang penilaian proses dan penilaian hasil belajar.

Pada buku panduan terdapat cover, kata pengantar, daftar isi, teori mengenai GI, permainan, media yang digunakan, penjelasan media, dan langkah-langkah kegiatan. Cover berisi judul dan gambar yang menarik dengan warna dominan hijau. Teori mengenai GI mencakup 3 teori yaitu Sherlock Holmes, Jean Piaget, dan Mildred Parten. Media yang digunakan yaitu kaca pembesar, kantong misi, dan kartu berkata.

\section{Pengembangan}

Pada tahap pengembangan, peneliti

(1) membuat rancangan perangkat pembelajaran berupa RPP, Buku Panduan, serta memilih media, (2) memvalidasi perangkat pembelajaran ke validator. Berikut uraian singkat rancangan perangkat pembelajaran dan hasil validasi perangkat pembelajaran.

a. Rancangan perangkat pembelajaran

1). Rencana Pelaksanaan Pembelajaran (RPP)

RPP disusun sebagai petunjuk guru dalam melaksanakan pembelajaran di dalam kelas. RPP ini berorientasi pada pembelajaran kurikulum 2013 yaitu dengan mengintegrasikan model GI dengan permainan . Di dalam RPP ini memuat kompetensi inti, kompetensi dasar, indikator pencapaian kompetensi, tujuan pembelajaran, uraian materi, metode, model, media, alat pembelajaran yang digunakan, kegiatan pembelajaran, alokasi waktu, dan penilaian. 
RPP pada kegiatan pendahuluan merupakan langkah pertama dari model pembelajaran GI yaitu mengidentifikasi topik dan mengatur murid ke dalam kelompok. Setelah itu pada kegiatan inti terdapat langkah selanjutnya yaitu merencanakan tugas yang akan dipelajari, melakukan investigasi, menyiapkan laporan akhir, mempresentasikan laporan akhir, dan evaluasi. Evaluasi yang dipilih yaitu evaluasi antar kelompok.

\section{2). Buku Panduan}

Buku panduan ini berisi tentang cara penggunaan model pembelajaran GI dengan permainan "aku seorang detektif". Permainan tersebut akan membuat siswa untuk memposisikan/membayangkan dirinya sebagai seorang detektif yang harus menjalankan sebuah penyelidikan untuk menemukan benda-benda yang hilang.

Buku panduan disusun sebagai petunjuk guru dalam melaksanakan model GI dengan permainan "aku seorang detektif". Buku panduan dicetak dengan ukuran A5 dengan kertas AP. Di dalam buku panduan ini memuat cover, kata pengantar, daftar isi, teori mengenai GI, permainan, media yang digunakan, penjelasan media, dan langkah-langkah kegiatan.

Teori mengenai GI yaitu tentang pengertian dari model pembelajaran GI yang dikutip dari beberapa buku. Permainan yaitu pengertian dari permainan "aku seorang detektif yang diambil dari teori detektif Sherlock Hormes. Media yang digunakan yaitu kaca pembesar,kartu berkata dan kantong misi.

Sesuai dengan sub materi yang dipilih dan rancangan RPP, maka media pembelajaran disesuaikan dengan permainan dan materi gaya dan gerak. Desain media pembelajaran dipilih semenarik mungkin agar siswa termotivasi dalam mengikuti kegiatan pembelajaran dan mempermudah siswa dalam proses kegiatan pembelajaran.

Media pembelajaran pendukung permainan "aku seorang detektif' yaitu kaca pembesar, kartu berkata dan kantong misi. Kaca pembesar terbuat dari lampu bekas yang berisi air dan memiliki fungsi untuk membaca misi pada kartu berkata dan pada misi kedua. Kartu berkata terbuat dari kertas AP yang dibentuk menyerupai kutipan dan berfungsi untuk menulis kata kunci dari benda yang hilang. Kantong misi terbuat dari kertas amplop yang berfungsi sebagai tempat diletakkannya 3 misi, dimana setiap misinya terbuat dari kertas AP, HVS dan kertas manila.

b. Validasi Perangkat Pembelajaran

Dalam penelitian ini, proses validasi dilaksanakan selama 1 minggu dengan validator yang berkompeten dan mengerti tentang pembelajaran kurikulum 2013 khususnya model GI dengan permainan pada materi gaya dan gerak. Saran-saran dari validator dijadikan masukan untuk merevisi perangkat pembelajaran sehingga perangkat pembelajaran siap untuk diimplementasikan ke obyek penelitian. Hasil validator digunakan untuk melihat kevalidan dari produk yang telah dibuat oleh peneliti.

Adapun validator yang dipilih dalam penelitian ini adalah Bapak Kuncahyono, M.Pd dan Bapak Ahmad Hafidh Imaduddin, S.Pd. Bapak Kuncahyono, M.Pd sebagai ahli permainan dengan memvalidasi angket RPP dan media permainan. Bapak Ahmad Hafidh Imaduddin, S.Pd sebagai ahli materi siswa SD merupakan guru kelas IVB di SD Muhammadiyah Malang dengan memvalidasi buku panduan.

1) Rencana Pelaksanaan Pembelajaran (RPP)

RPP disusun sebagai petunjuk guru dalam melaksanakan pembelajaran di dalam kelas yang berupa langkahlangkah yang disusun secara terstruktur yang disesuaikan dengan pendekatan saintifik pada kurikulum 2013. RPP ini 
berorientasi pada pembelajaran kurikulum 2013 yaitu mengembangkan model GI dengan permainan "aku seorang detektif". Di dalam RPP ini memuat kompetensi inti, kompetensi dasar, indikator pencapaian kompetensi, tujuan pembelajaran, uraian materi, metode, model, media, alat pembelajaran yang digunakan, kegiatan pembelajaran, alokasi waktu, dan penilaian. RPP di uji kevalidan oleh Bapak Kuncahyono, M.Pd sebagai ahli permainan.

Hasil Validasi Angket RPP, didapatkan skor total dari validator sebesar 61. Dengan mencocokkan persentase dengan kategori yang ditetapkan oleh Vicy (2016:35) skor persentase sebesar 98\%, RPP yang dikembang termasuk dalam kategori sangat layak. Adapun kometar dan saran dari validator yaitu keseluruhan RPP sudah bagus dan sesuai dengan pengembangan model pembelajaran GI dengan permainan "aku seorang detektif". Hasil validasi selengkapnya disajikan dalam lampiran.

2). Buku Panduan

Buku panduan disusun sebagai petunjuk guru dalam melaksanakan model GI dengan permainan "aku seorang detektif". Di dalam buku panduan ini memuat cover, kata pengantar, daftar isi, teori mengenai GI, permainan, media yang digunakan, penjelasan media, dan langkah-langkah kegiatan. Produk yang dihasilkan adalah sebuah permainan dimana siswa memposisikan/membayangkan dirinya sebagai seorang detektif yang harus menjalankan sebuah penyelidikan untuk menemukan barang-barang yang hilang. Buku panduan di uji kevalidan oleh Bapak Ahmad Hafidh Imaduddin, S.Pd sebagai ahli materi sekaligus pengguna.

Hasil Angket Ahli Materi/Pengguna Buku Panduan, didapatkan skor total dari validator sebesar 25. Mencocokkan persentase dengan kategori yang ditetapkan oleh Vicy (2016:35) diperoleh skor persentase sebesar $89 \%$, RPP yang dikembang termasuk dalam kategori sangat layak. Adapun saran dari validator yaitu ukuran buku panduan dibuat kecil agar bisa dimasukkan dalam kotak media dan cover dicetak dengan kertas yang lebih tebal. Hasil validasi selengkapnya disajikan dalam lampiran.

Sesuai dengan sub materi yang dipilih dan rancangan RPP, maka media pembelajaran pendukung permainan dipilih sesuai materi gaya dan gerak. Desain dipilih semenarik mungkin agar siswa termotivasi dalam mengikuti kegiatan pembelajaran dan mempermudah siswa dalam proses kegiatan pembelajaran. Media pembelajaran pendukung permainan di uji kevalidan oleh Bapak Kuncahyono, M.Pd sebagai ahli permainan. Hasil Validasi Angket Permainan dan Media Pendukung Permainan, didapatkan skor total dari validator sebesar 33. Dengan mencocokkan persentase dengan kategori yang ditetapkan oleh Vicy (2016:35) diperoleh skor persentase sebesar 92\%, media pendukung permainan yang dikembang termasuk dalam kategori sangat layak. Adapun saran dari validator yaitu font pada media dicetak lebih baik, media dapat dicetak di kertas yang kuat/ dilaminating agar kuat dan awet. Hasil validasi selengkapnya disajikan dalam lampiran.

Berdasarkan hasil yang dari validator di atas dapat disimpulkan bahwa perangkat pembelajaran yang meliputi RPP dan buku panduan serta media pendukung permainan. Masing-masing produk dapat dilaksanakan di lapangan dengan sedikit revisi. RPP dan buku panduan serta media pendukung permainan dikatakan sangat layak untuk digunakan.

\section{Penerapan}

Pada langkah implementasi ini dilakukan terbatas pada sekolah tertentu. Sekolah yang dimaksud pada penelitian ini adalah SD Muhammadiyah 1 Malang. Langkah implementasi diasosiasikan 
dengan penyelenggaraan program pembelajaran itu sendiri yaitu adanya penyampaian materi pembelajaran dari guru atau instruktur kepada siswa. Implementasi ini bertujuan untuk mendapatkan masukan secara langsung dari guru maupun siswa yang telah mengikuti pembelajaran. Pembelajaran yang diterapkan adalah pembelajaran model GI dengan permainan "Aku Seorang Detektif" pada materi gaya dan gerak. Implementasi dilakukan pada kelas IVB SD Muhammadiyah 1 Malang pada semester genap tahun ajaran 20172018 dengan jumlah siswa 22.

Kegiatan pembelajaran terdiri dari kegiatan pendahuluan, inti dan penutup. Pada kegiatan pendahuluan yaitu terdiri dari a) berdoa; b) absensi kehadiran; c) menginformasikan tema,subtema dan tujuan pembelajaran; d) membahas materi sebelumnya; e) apersepsi; dan f) siswa dibagi dalam kelompok. Pada kegiatan inti yaitu terdiri dari a) siswa diajak pembelajaran di luar kelas; b) guru menjelaskan aturan permainan "aku seorang detektif"; c) melaksanakan permainan "aku seorang detektif"; d) menulis laporan hasil pengamatan pada LKS; e) Mempresentasikan laporan hasil pengamatan; f) kelompok lain memberikan pertanyaan. Pada kegiatan penutup yaitu terdiri dari a) mengevaluasi hasil presentasi bersama guru; b) menyampaikan pendapat dan menyimpulkan kegiatan; dan c) mengerjakan soal post test.

Pada tahap penerapan, dihasilkan data mengenai respon guru/pengguna kelas IV B selaku wali kelas selama PBM dan respon siswa. Respon guru akan menilai keefektifan produk sedangkan respon siswa akan menilai kemenarikan produk.

\section{Evaluasi}

Tahap evaluasi pada model ADDIE didefinisikan sebagai sebuah proses yang dilakukan untuk memberikan nilai terhadap program pembelajaran. Selain itu, evaluasi juga dapat dilakukan dengan cara melihat respon siswa maupun respon guru. Evaluasi juga terdapat pada setiap langkah ADDIE. Hasil Angket Respon Guru Ketika Proses Pembelajaran, didapatkan skor total dari validator sebesar 24. Hasil respon guru digunakan untuk melihat efektif atau tidaknya perangkat pembelajaran yang telah dibuat oleh peneliti. Dengan mencocokkan persentase dengan kategori yang ditetapkan oleh Vicy (2016:35) diperoleh skor persentase sebesar $86 \%$, model pembelajaran GI yang dikembangkan termasuk dalam kategori sangat efektif. Adapun saran dari guru yaitu pada laporan penelitian seharusnya siswa membuat format laporan sendiri sehingga siswa lebih mudah menyampaikan hasil pengamatan ketika presentasi. Hasil Angket Respon Siswa, didapatkan skor total dari validator sebesar 209. Hasil respon siswa digunakan untuk melihat menarik atau tidaknya perangkat pembelajaran yang telah dibuat oleh peneliti. Dengan mencocokkan persentase dengan kategori yang ditetapkan oleh Vicy (2016:35) diperoleh skor persentase sebesar 95\%, model pembelajaran GI yang dikembang termasuk dalam kategori sangat layak. Hasil validasi selengkapnya disajikan dalam lampiran.

1. Kevalidan Produk

Uji kevalidan pada perangkat pembelajaran ini dilakukan oleh dua orang ahli. Satu ahli permainan yaitu Bapak Kuncahyono, M.Pd, memberikan penilaian pada Rencana Pelaksanaan Pembelajaran (RPP) dan media pendukung permainan serta satu ahli materi yaitu Bapak Ahmad Hafidh Imamuddin, S.Pd memberikan penilaian pada Buku Pedoman.

Kevalidan produk menggunakan validitas teoritik(validitas logika). Validitas teoritik lebih menekankan pada tingkat ketepatan alat evaluasi ditinjau dari isi alat evaluasi tersebut. Oleh karena itu validitas teoritik lebih tepat dilakukan dengan meminta pertimbangan pakar. 
Tentunya pakar yang dimaksud adalah orang-orang yang memiliki keahlian pada bidangnya(Sudiono, 2009:26).

a. Kevalidan RPP

Rencana pelaksanaan pembelajaran yang dikembangkan oleh peneliti dalam penelitian ini telah memenuhi kriteria valid. Hal ini berdasarkan pada tabel 4.4 hasil angket RPP sesuai dengan Vicy (2016:35) yang mencapai skor persentase 98\%. Walaupun demikian masih diperlukan perbaikan dan penyempurnaan lebih lanjut atau penyesuaian-penyesuaian jika RPP akan diterapkan pada kondisi lain.

\section{b. Kevalidan Buku Pedoman}

Buku pedoman yang dikembangkan dalam penelitian ini telah memenuhi kriteria valid. Hal ini berdasarkan pada tabel 4.5 hasil angket buku pedoman sesuai dengan Vicy (2016:35) yang mencapai skor persentase $89 \%$. Namun demikian, buku pedoman yang dikembangkan masih memerlukan perbaikan jika buku pedoman akan diterapkan pada materi yang lain.

Media pendukung permainan dalam penelitian ini telah memenuhi kriteria valid. Media dikatakan valid jika mengandung prinsip VISUALS yaitu 1) Mudah dilihat(visible); 2) Menarik (interesting); 3) sederhana (simple); 4) bermanfaat (useful); 5) Benar(accurate); 6) Masuk akal (legitimate); dan 7) terstruktur (structured) (Nurseto, 2011: 24). Hal ini berdasarkan pada hasil analisis data permainan dan media pendukung permainan, hasil angket permainan dan media pendukung permainan sesuai dengan Vicy (2016:35) mencapai skor persentase 92\%. Namun demikian, media dan permainan yang dikembangkan masih memerlukan perbaikan jika media dan permainan akan diterapkan pada materi yang lain.

Berdasarkan uraian di atas, maka dapat disimpulkan bahwa model pembelajaran GI dengan "aku seorang detektif" pada materi gaya dan gerak yang dikembangkan dapat dikatakan sangat valid atau sangat layak digunakan.

2. Keefektifan Produk

Guru merupakan salah satu faktor yang mempengaruhi hasil pelaksanaan dari pembelajaran yang telah diterapkan, sebab guru adalah pengajar di kelas. Keefektifan perangkat pembelajaran diambil dari hasil angket respon guru ketika proses pembelajaran. Pembelajaran merupakan komunikasi dua arah, kegiatan guru sebagai pendidik harus mengajar dan murid sebagai terdidik yang belajar. Maka pembelajaran dapat dikatakan efektif, apabila dapat memfasilitasi pemerolehan pengetahuan dan keterampilan siswa melalui penyajian informasi dan aktivitas yang dirancang untuk membantu memudahkan peserta didik dalam rangka mencapai tujuan khusus belajar yang diharapkan. Jadi Produk dikatakan efektif jika guru dapat melaksanakan serangkaian kegiatan pembelajaran untuk mencapai tujuan pembelajaran (Saadi, 2013: 6). Berdasarkan respon guru dalam pelaksanaan pengembangan model pembelajaran GI ini telah memenuhi kriteria sangat efektif. Hasil respon guru/ penguna sesuai dengan Vicy (2016:35) yang mencapai skor persentase $86 \%$.

\section{Kemenarikan Produk}

Kemenarikan produk dapat dilihat dari respon siswa ketika melakukan proses belajar mengajar. Anak-anak usia sekolah memiliki karakteristik yang berbeda dengan anak-anak yang usianya lebih muda. Ia senang bermain, senang bergerak, senang bekerja dalam kelompok, dan senang merasakan atau melakukan sesuatu secara langsung (Supriadi, 2010: 80).

Respon siswa ini, berupa angket respon siswa yang berupa pernyataan dan berupa pilihan "ya" dan "tidak". Hasil Respon Siswa menunjukkan bahwa banyak siswa yang minat terhadap model pembelajaran GI dengan permainan "aku seorang detektif". Sesuai dengan Vicy (2016:35) dengan persentase $95 \%$ siswa 
yang setuju, $5 \%$ siswa yang tidak setuju terhadap angket respon siswa dari 10 pernyataan yang dibuat oleh peneliti. Maka dapat disimpulkan bahwa model pembelajaran GI dengan permainan "aku seorang detektif" pada materi gaya dan gerak yang dikembangkan dapat dikatakan menarik. Hal ini sesuai dengan pendapat Supriadi (2010: 80). Maka model pembelajaran GI yang dikembangkan dengan permainan "aku seorang detektif' dikatakan sangat layak.

\section{SIMPULAN}

Penelitian pengembangan model pembelajaran GI dengan permainan "aku seorang detektif" kelas IV SD Muhammadiyah 1 Malang menghasilkan kevalidan,keefektifan dan kemenarikan. Pada hasil kevalidan sebesar $89 \%$ pada validasi buku pedoman, $98 \%$ pada validasi RPP dan $92 \%$ pada validasi media. Skor tersebut menunjukkan bahwa permainan tersebut sangat valid dan sangat layak untuk digunakan. Pada hasil keefektifan sebesar $86 \%$ pada respon guru selama PBM. Skor tersebut menunjukkan bahwa permainan tersebut sangat efektif dan sangat layak untuk digunakan. Pada hasil kemenarikan sebesar $95 \%$ siswa yang setuju, $5 \%$ siswa yang tidak setuju terhadap angket respon siswa dari 10 pernyataan yang dibuat oleh peneliti pada respon siswa. Hal ini menunjukkan bahwa model pembelajaran yang dikembangkan dengan permainan dinyatakan sangat menarik. Pada beberapa data diatas, dapat disimpulkan bahwa pengembangan model pembelajaran GI dengan permainan "aku seorang detektif" dalam materi gaya dan gerak pada kelas IV SD Muhammadiyah 1 Malang dinyatakan sangat layak.

\section{DAFTAR PUSTAKA}

Akbar, Sa'dun. 2016. Instrumen Perangkat Pembelajaran. Bandung: PT Remaja Rosdakarya.
BNSP Indonesia. 2009. Lampiran Permendikbud No 22 Tahun 2016, (Online), (http:/ pdf. BNSP Indonesia. org), diakses 2 Januari 2017.

Dhienzzworld. 2013. Teknik dan Metode Detektif, (Online), (https: //dhienzzworld. wordpress. com/ 2013/ 04/ 29/ teknik-dan-metodedetektif/), diakses 25 Februari 2017.

E. Slavin, Robert. 2005. Cooperative Learning. Terjemahan Narulita. 2014. Bandung : Nusa Media.

Insani, Wening. 2011. Perancangan Buku Visual Cara Membuat Mainan Tradisional, (online), (http:// digilib. its. ac. id/ public/ ITSUndergraduate-14167-3406100110Conclusion .pdf), diakses 2 Januari 2017.

Majid,Abdul. 2014. Pembelajaran Tematik Terpadu. Bandung : Remaja Rosdakarya.

Mantara, Angga Yuni. 2014. Pengembangan Permainan Konstruktif Kata Sebagai Alat Ukur Kemampuan Berbahasa Pada Siswa Kelas III SDN Karangbesuki 1 dan 2. Skripsi. Malang: Psikologi UM.

Meiliya, Nadlifa. 2016. Penerapan Model Pembelajaran Group Investigation Untuk Meningkatkan Hasil Belajar Siswa, (Online), (http:// jurnal. unmuhjember. ac. id/ index. php/ BIOMA/ article/ download/ 157/94), diakses 2 Januari 2017.

Nofida, dkk. 2013. Pengembangan Perangkat Pembelajaran Menerapkan Model Pembelajaraan Kooperatif Tipegroup Investigation(GI) Berbantuan Softwaremultisim, (Online), (http:// ejournal. unesa. ac. id/ article/ 7295/ 
44/ article. pdf), diakses 2 Januari 2017.

Radiyanti, Siti, dkk. 2012. Penggunaan Model Pembelajaran Kooperatif Tipe Group Investigation Dalam Peningkatan Hasil Belajar IPS di Kelas IV SD, (Online), (http:// jurnal. fkip. uns. ac. id/ index. php/ pgsdkebumen/ article/ download/ 285/ 165\%201\%202. html), diakses 2 Januari.

Rini, Titis Angga. 2015. Pengembangan Metode Permainan Edukatif Detektif Cilik Pada Pembelajaran Keindahan Alam Negeriku di Kelas IV SDN Bendogerit 01 Kota , (online), (http:// mulok. library. um. ac. id/ index3. php/ 68466. html), diakses 2 Januari 2017.

Riyansari, Ira. 2016. Ilmu Pengetahuan Alam. Sukoharjo: Hasan Pratama.

Setyawanto,Agung. 2012. Rencana Pelaksanaan Pembelajaran (RPP) Guru Bahasa Indonesia Tingkat Smp Di Kota Malang, (online), (http:// jurnal-online. um. ac. id/ data/ artikel/ artikelB75014B49ADF96FF1A3C8 A A02E089935. pdf), diakses 2 Januari 2017.

Shoimin,Aris. 2014. 68 Model Pembelajaran Inovatif dalam Kurikulum 2013.Yogyakarta : Arruz Media.

Sudiono, Anas. 2009.Pengantar Evaluasi Pendidikan. Jakarta: Rajawali Press.

Saadi, Fransiska. 2013. Peningkatan Efektivitas Belajar Peserta Didik Dalam Pembelajaran Ilmu Pengetahuan Sosial Menggunakan Media Tepat Guna Di Kelas IV Sekolah Dasar Negeri 02 Toho, (online),

(http://download.portalgaruda.org/art icle.php? article $=112098 \& v a l=2338$ ), diakses 2 Januari 2017.

Sukini. 2012. Pembelajaran Tematik Di Sekolah Dasar Kelas Rendah Dan Pelaksanaannya, (online), (http:// journal. unwidha. ac. id/ index.php/ magistra/ article/ viewFile/ 292/241), diakses 2 Januari 2017.

Supriadi, Oding. 2010. Perkembangan Peserta Didik. Yogyakarta: Kurnia Kalam Semesta.

Supriyanti. 2010. Peningkatan Aktivitas Siswa Materi Gaya Dan Gerak IPA Melalui CD Interaktif dengan Pendekatan Kontekstual Pada Kelas IV SDN I Tegorejo Kab. Kendal, (Online), (http:// lib. unnes. ac. id/ 2913/ 1/ 3382. pdf), diakses 2 Januari 2017.

Sutirna. 2013. Perkembangan dan Pertumbuhan Peserta Didik. Yogyakarta: Andi.

Tegeh, I Made. 2014. Model Penelitian Pengembangan. Yogyakarta: Graha Ilmu.

Vicy, Metalia. 2016. Pengembangan Media Pohon Berhitung Pada Pembelajaran Matematika Untuk Siswa Kelas 1 SD. Skripsi. Malang: PGSD UMM.

Widyastuti, Eny. 2013. Meningkatkan Minat Belajar Menggunakan Permainan Tangram Pada Mata Pelajaran Matematika Bagi Kelas II SD Negeri Dukun 2 Kecamatan Dukun Magelang, (Online), (http:// eprints. uny. ac. id/ 15994/ 1/ Eny\%20Widyastuti (skripsi). pdf), diakses 2 Januari 2017. 